\title{
KETEPATAN PEMBERIAN OPINI AUDIT OLEH AKUNTAN \\ PUBLIK DAN FAKTOR-FAKTOR YANG MEMPENGARUHI: STUDI KASUS PADA KANTOR AKUNTAN PUBLIK DI BANTEN
}

\author{
Dirvi Surya Abbas (1) \\ Universitas Muhammadiyah Tangerang \\ abbas.dirvi@gmail.com \\ Basuki ${ }^{(2)}$ \\ Universitas Muhammadiyah Tangerang \\ mr.basuki.tng@gmail.com
}

\begin{abstract}
This study aims to explain the influence of Independence, Audit Skills, Accounting Knowledge and Auditors' and Skepticism on the Accuracy of Audit Opinion. This research uses purposive sampling and accidental sampling techniques. After distributing the questionnaire, a sample of 30 auditors who were respondents were taken from a public accounting firm located in Banten province. Hypothesis testing in this study was carried out using multiple linear regression analysis.

In the results of this study revealed that the variable independence and Knowledge of Accounting and Audit partially affect the Accuracy of Giving Audit Opinion. Whereas the variable Audit Expertise and Auditor Skeptism partially do not have an influence on the accuracy of the Audit Opinion.
\end{abstract}

Keywords: The auditor's attitude factor and the accuracy of the giving of audit opinions 


\section{PENDAHULUAN}

Diawal tahun 2020 terangkat ke media massa akan Kasus gagal bayar polis nasabah yang mengarah pada korupsi PT Asuransi Jiwasraya dinilai melibatkan banyak pihak termasuk akuntan publik. Auditor dianggap tidak mampu atau mengungkap kondisi sebenarnya pada Jiwasraya. Terlebih lagi, laporan keuangan teraudit yang dipublikasikan Jiwasraya ternyata telah dimanipulasi atau window dressing sehingga perusahaan terlihat sehat. Dalam laporan keuangan Jiwasraya 2017, misalnya, akuntan publik telah memberikan pendapat "opini dengan modifikasi". Opini tersebut mencakup salah satu dari tiga jenis opini auditor yaitu opini wajar dengan mengecualian, opini tidak wajar dan opini tanpa memberikan pendapat. "Opini ini disebabkan karena tidak sesuainya material laporan keuangan dengan standar akuntansi atau karena auditor kekurangan memperoleh bukti karena berbagai sebab sehingga tidak cukup untuk memberikan opini wajar tanpa pengecualian. (CNN Indonesia; 2020).

Lalu sebelumnya akhir tahun 2019 telah juga terjadi kasus yang dilakukan oleh akuntan publik sehingga mendapatkan sanksi dari kemenkeu yakni ditemukannya Akuntan publik yang mengaudit laporan keuangan PT Garuda Indonesia Tbk (GIAA) 2018 yaitu Kasner Sirumapea di duga telah melakukan pelanggaran pelanggaran Pasal 69 UndangUndang Nomor 8 Tahun 1995 tentang Pasar Modal (UU PM), Peraturan Bapepam dan LK Nomor VIII.G.7 tentang Penyajian dan Pengungkapan Laporan Keuangan Emiten dan Perusahaan Publik, Interpretasi Standar Akuntansi Keuangan (ISAK) 8 tentang Penentuan Apakah Suatu Perjanjian Mengandung Sewa, dan Pernyataan Standar Akuntansi Keuangan (PSAK) 30 tentang Sewa. tanggal 18 Januari 2019, dan juga Kasner Sirumapea di duga telah melakukan pelanggaran terkait Standar Audit (SA) 315 Standar Profesional Akuntan Publik (SPAP) yakni perihal Pengidentifikasian dan Penilaian Risiko Kesalahan Penyajian Material Melalui Pemahaman atas Entitas dan Lingkungannya,
SA 500 SPAP tentang Bukti Audit, SA 560 SPAP tentang Peristiwa Kemudian, dan SA 700 SPAP tentang Perumusan Suatu Opini dan Pelaporan atas Laporan Keuangan. Atas perbuatannya tersebut Kasner Sirumapea diganjar hukuman pembekuan izin usaha selama 12 bulan oleh Kementerian Keuangan. (Abbas \& Basuki; 2019).

Lalu Kasus Pelanggaran yang dilakukan Akuntan Publik diatas adalah yang terjadi didalam negeri, namun ada juga macam-macam skandal akuntansi berskala besar yang terjadi diluar negeri yakni kasus yang melibatkan auditor KAP Delloite \& Touche, karena telah diduga gagal dalam menangkap sinyalemen penyelewengan dana yang akhirnya menyeret klien perusahaannya yakni Taylor, Bean \& Whitaker Mortgage Corp. (TBW) menuju ke kebangkrutan. Hal ini berawal dari opini yang dikeluarkan oleh KAP Delloite \& Touche yang menyatakan bahwa perusahaan tersebut dianggap telah memiliki kemampuan dalam memenuhi segala kewajiban, bisa dipercaya, dengan laporan keuangan yang akurat setiap tahunnya dari 2001 hingga 2008. Namun, nyatanya hal tersebut bertolak belakang dengan hasil opini yang diterima oleh KAP Delloite \& Touche. Sehingga kliennya yakni Taylor, Bean \& Whitaker Mortgage Corp. menuntut auditor KAP Deloitte kepengadilan, karena auditor KAP Deloitte telah gagal mendeteksi adanya fraud karena auditor KAP Deloitte tersebut tidak mempertimbangkan preferensi dari pihak manajemen kliennya atas transaksitransaksi mencurigakan yang komplikasi, tidak lengkap, dan sering disampaikan sangat terlambat. Namun, preferensi kliennya tersebut dianggap tidak masuk akal dan bertolak belakang dengan dokumen-dokumen yang telah dikantongi oleh auditor KAP Deloitte sebelumnya. (jurnal.akuntansi.keuangan; 2011).

Hal ini membuktikan walaupun sudah ada standar dan kode etik profesi sekalipun, tetapi masih sering terjadi skandal - skandal akuntansi yang melibatkan para akuntan publik sehingga masyarakat mulai menyangsikan komitmen auditor terhadap kode etik profesinya. Jika kode etik dan standar dijalankan dengan benar dan konsisten, 
maka kasus - kasus skandal tersebut tidak akan terjadi. Seperti yang tercantum didalam Standar Umum No. 2 dikatakan bahwa Auditor diharuskan mempertahankan sikap mental yang independen dalam semua hal yang berhubungan dengan audit (Abbas \& Basuki; 2019).

Berbicara tentang kode etik, pelanggaran dalam kode etik berdasarkan permasalahan dalam kasus diatas seringkali terdapat dalam tahap akhir dalam proses audit yakni laporan auditor yang dijadikan dasar dalam memberikan opini mengenai kewajaran suatu laporan keuangan yang diaudit, apakah sudah sesuai dengan PSAK. Opini audit menurut Kamus Standar Akuntansi menurut Fatiah (2014) adalah merupakan suatu laporan yang diberikan seseorang akuntan publik terdaftar sebagai hasil penilaiannya terhadap kewajaran laporan keuangan yang sudah disajikan perusahaan dan diperiksa kehandalannya. Auditor harus merumuskan suatu penilaian berdasarkan laporan keuangan yang telah disusun oleh perusahaan apakah semua hal yang material, sudah sesuai dengan batas standar yang mengacu kepada kerangka pelaporan keuangan yang berlaku (PSAK). Untuk merumuskan opini tersebut, akuntan publik harus dapat memastikan apakah auditor yang telah membuat laporan audit tersebut sudah menyakini tentang laporan keuangan secara keseluruhan, bisa membuktikan bahwa laporan audit telah bebas dari kesalahan penyajian material, baik yang disebabkan oleh kecurangan maupun kesalahan (Standar Profesional Akuntan Publik 2016).

Komunikasi tentang temuan -temuan auditor yang dituangkan kedalam laporan keuangan auditan merupakan hal yang penting. Banyak pihak yang sangat bergantung tentang kepastian dari hasil laporan keuangan auditan yang telah mereka buat, terutama pelaku bisnis. Konsekuensi atas ketidaktepatan pemberian opini audit tentang informasi yang terdapat dalam laporan keuangan auditan tersebut, tentunya selain merugikan pembaca laporan tersebut, tentunya akan menyebabkan kantor akuntan publik yang berkaitan akan dikenakan sanksi atas tindakannya. Maka dari itu, didalam laporan auditor sebaiknya mampu menyatakan bahwa tanggung jawab akuntan publik mampu memberikan penilaian suatu pendapat atas laporan keuangan berdasarkan hasil audit auditor dilapangan, dan serta memastikan bahwa audit telah dilakukan dengan menggunakan Standar Audit yang telah ditetapkan oleh organisasi. Didalam SPAP (standard professional akuntan publik) terdapat lima jenis opini audit yang bisa diterapkan berdasarkan hasil temuan auditor dilapangan, yaitu pendapat wajar tanpa pengecualian (WTP), pendapat wajar tanpa pengecualian dengan bahasa penjelas, pendapat wajar dengan pengecualian (WDP), pendapat tidak wajar, dan tidak memberikan pendapat.

Standar umum yang wajib dipatuhi oleh auditor terkait tentang pelaporan audit terdapat dua standar. Pertama, standar audit disebutkan bahwa audit harus dilaksanakan oleh seorang atau yang memiliki kecakapan audit (keahlian dan pelatihan) yang cukup, agar layak mengemban tugas sebagai auditor. selanjutnya, standar umum ketiga menyebutkan bahwa dalam interaksi audit dalam penyusunan laporannya, auditor diharuskan mengandalkan kemahiran professional auditnya dengan handal dan relevan (SPAP, 2012). Maka dari itu, seorang auditor diwajibkan mempunyai kecakapan profesional serta keahlian audit.

Pengertian Keahlian audit yang wajib dimiliki oleh auditor mencakup seluruh pemahaman auditor tentang audit itu sendiri, adapun kriteria auditor dapat dikatakan sudah memiliki pemahaman audit yang handal ialah auditor bersertifikasi pendidikan Akuntan Publik dan memiliki jenjang pendidikan formal. Keahlian auditor merupakan faktor utama yang harus dimiliki oleh seorang auditor independen dalam mendukung pekerjaannya sebagai profesi ahli dibidangnya. Menurut (Merici et al., 2014) beberapa keahlian Auditor yang diperlukan dalam tugasnya, mencakup perencanaan program kerja pemeriksaan, menyusun program kerja pemeriksaan, melaksanakan program kerja pemeriksaan, menyusun kertas kerja pemeriksaan, menyusun berita pemeriksaan, dan laporan hasil pemeriksaan

Pengetahuan tentang audit dapat ditempuh melalui pendidikan formal dan pelatihan khusus seperti mengikuti kegiatan seminar, lokakarya atau bahkan dari 
komunikasi dengan rekan sejawat yang sudah lebih senior. Pengetahuan juga bisa diperoleh dari banyaknya jam penugasan saat melakukan tugasnya dalam proses audit dilapangan. Dengan demikian, seorang auditor yang melakukan tugasnya dengan sesuai pengetahuan yang dimilikinya akan menemukan temuan audit berbeda kualitas informasinya dibandingkan dengan auditor pemula yang belum handal tentang tugasnya dalam menemukan temuan audit. Dalam menentukan tingkat batas standar materialitas temuan audit, biasanya auditor pemula belum begitu memahaminya. Sehingga segala selisih yang terdapat didalam laporan keuangan akan dimasukkan kedalam temuan audit yang penting. Auditor harus telah menjalani pendidikan dan pelatihan teknis yang cukup dalam praktik akuntansi dan teknik auditing sehingga mampu menjalankan tugasnya dengan baik dan tepat (Pardede, 2015)

Di dalam Standar Profesional Akuntan Publik (2012) dikatakan bahwa suatu sikap yang mencakup pikiran yang selalu mempertanyakan dan melakukan evaluasi secara kritis terhadap bukti audit adalah suatu skeptisme professional dari auditor. Skeptisme profesional digabungkan ke dalam literatur profesional yang membutuhkan auditor untuk mengevaluasi kemungkinan kecurangan material. (Pardede, 2015)

Berdasarkan penjelasan diatas, dapat dikatakan bahwa hal-hal yang mendasari seorang auditor dapat menghasilkan suatu audit yang berkualitas, diwajibkan menggunakan kemahiran keprofesionalannya. kemahiran profesional auditor didapatkan dari hasil mengikuti pelatihan dan pengalaman auditnya. Namun banyaknya pelanggaran etika profesi yang terjadi seperti yang telah diangkat seolah-olah bersumber dari banyaknya pelatihan dan pengalaman yang telah mereka ikuti tersebut. Sehingga dapat melakukan teknik-teknik yang tidak didapatkan dalam bangku perkuliahan atau konferensi ilmiah. Seperti yang telah dijelaskan, terdapat beberapa KAP yang dibekukan karena telah memanfaatkan celah dari kelemahan standar etika suatu profesi. Adapun tujuan dari pelanggaran tersebut terjadi bukanlah tanpa suatu alasan.

Dengan berdasarkan pada latar belakang penelitian yang diuraikan sebelumnya. penelitian ini merumuskan bahwa, dalam menjalankan tugasnya Auditor memeriksa kewajaran dari entitas klien, baik itu entitas bisnis, organisasi maupun lainnya, dan semuanya berkaitan dengan klien. Selain bukti-bukti yang relevan, dalam proses audit juga membutuhkan informasi-informasi yang dapat membantu jalannya pemeriksaan. penjelasan dari klien inilah yang nantinya akan menjadi bahan pertimbangan Akuntan Publik. namun, hal tersebut tidak terlepas dari tingkat keakuratan informasi yang disampaikan, jadi baik secara langsung maupun tidak langsung informasi klien akan mempengaruhi Auditor dalam mempertimbangkan evaluasi auditnya. maka dari itu, untuk membuat opini audit yang baik demi tercapainya mutu dan kualitas audit yang baik, Pertimbangan terhadap evaluasi bukti sangat erat kaitannya dengan karakteristik personal seperti Independensi auditor, Keahlian, pengetahuan akuntansi dan auditing, skeptisme auditor. Selanjutnya, masih sedikit penelitian yang mengaitkan hal tersebut, maka dari itu penelitian ini diberi judul: "Ketepatan Pemberian Opini Audit Oleh Akuntan Publik Dan Faktor-Faktor Yang Mempengaruhi: Studi Kasus Pada Kantor Akuntan Publik Di Banten "

\section{KAJIAN LITERATUR PENGEMBANGAN HIPOTESIS Theory of Planned Behavior (TPB)}

Menurut Ajzen (1991) Theory Planned of Behavior ini didasarkan pada asumsi bahwa manusia biasanya akan berperilaku pantas (behave in a sensible manner). Tujuan dan manfaat dari teori ini adalah untuk meramalkan dan memahami pengaruhpengaruh motivasi perilaku, baik kemauan individu itu sendiri maupun bukan kemauan dari inidividu tersebut. Pada dasarnya teori ini merupakan fungsi dari tiga dasar determinan 
yaitu attitude toward the behavior, subjective norm dan perceived behavioral control.

Seperti yang telah dijelaskan didalam

Theory of Planned Behavior, dalam berperilaku seseorang diarahkan oleh beberapa hal atau kepercayaan. Begitu pula dengan auditor, dalam berperilaku dalam konteks ini membuat pertimbangan auditnya dipengaruhi hal-hal tersebut.

\section{Pengaruh Independensi Terhadap Pemilihan Ketepatan pemberian Opini Audit}

Berdasarkan hasil penelitian yang dilakukan oleh Merici, Halim \& Wulandari (2016) menyatakan bahwa independensi berpengaruh signifikan terhadap ketepatan pemberian opini oleh akuntan publik berdasarkan hasil temuan laporan audit yang dibuat oleh auditor selama dilapangan, hasil penelitian tersebut tidak sejalan dengan hasil penelitian yang dilakukan oleh Kautsarrahmelia (2013) yang menyatakan bahwa independensi tidak berpengaruh terhadap ketepatan pemberian opini audit. terdapatnya campur tangan dari klien terhadap laporan yang dibuat oleh auditor seperti keikutsertaan klien dalam menentukan, mengkonfirmasi, mengkoreksi pembukuan, serta adanya campur tangan dari klien dalam menentukan prosedur-prosedur yang akan diterapkan oleh auditor dalam proses auditnya. Berdasarkan adanya hasil perbedaan penelitian tersebut, maka hipotesis yang diajukan adalah:

$\mathrm{H}_{1}$ : Independensi berpengaruh terhadap Ketepatan pemberian opini audit.

\section{Pengaruh Keahlian Audit Terhadap Pemilihan Ketepatan pemberian Opini Audit}

Berdasarkan hasil penelitian yang dilakukan oleh Marheni, L \&., Cahyono, Y. T. (2018) menunjukkan bahwa jika variabel Keahlian audit dalam penelitiannya memiliki pengaruh terhadap ketepatan pemberian opini oleh akuntan publik berdasarkan hasil temuan laporan audit yang dibuat oleh auditor selama dilapangan. Namun, hasil penelitian tersebut berbeda dengan hasil penelitian yang dilakukan oleh Pardede, H,. Rasuli, M,. Silfi, A. (2015) didalam hasil penelitiannya tersebut menyatakan bahwa jika variabel keahlian audit dalam penelitiannya tidak memiliki pengaruh terhadap ketepatan pemberian opini oleh akuntan publik berdasarkan hasil temuan laporan audit yang dibuat oleh auditor selama dilapangan. hal ini dikarenakan bahwa keahlian audit bukan ditentukan oleh berdasarkan tingkat pendidikan formal maupun bersifat pelatihan atau Seminar baik itu yang bersifat peningkatan karir profesi atau hanya sebagai penambah pengetahuan keahlian audit saja. Berdasarkan adanya perbedaan dari hasil penelitian tersebut, maka hipotesis yang diajukan adalah:

$\mathrm{H}_{2}$ : Keahlian Audit berpengaruh terhadap Ketepatan pemberian Opini Audit.

\section{Pengaruh Pengetahuan akuntansi dan auditing Terhadap Pemilihan Ketepatan pemberian Opini Audit}

Hipotesis selanjutnya adalah terkait dengan variabel pengetahuan akuntansi dan auditing yang dimiliki oleh auditor. Berdasarkan hasil penelitian yang dilakukan oleh Pardede, H,. Rasuli, M,. Silfi, A. (2015) dalam hasil penelitiannya menyatakan bahwa jika variabel pengetahuan akuntansi dan auditing memiliki berpengaruh secara signifikan dan positif terhadap ketepatan pemberian opini oleh akuntan publik berdasarkan hasil temuan laporan audit yang dibuat oleh auditor selama dilapangan, adanya tingkat perbedaan pengetahuan di antara beberapa auditor akan berpengaruh terhadap menyelesaikan laporan auditnya dengan handal. Dengan kata lain bahwa setiap tindakan dan keputusan yang diambil oleh auditor selama proses audit harus mengacu kepada pengetahuannya tentang bidang ilmu akuntansi dan audit. Hal tersebut sangatlah penting khususnya bagi profesi auditor eksternal dikarenakan didalam pekerjaannya tersebut, akan selalu berkaitan dengan akuntansi dan auditing maka pengetahuan yang luas tentang akuntansi dan auditing merupakan dasar syarat yang mesti dimiliki oleh auditor, karena laporan audit yang dibuat oleh auditor selama dilapangan akan menjadi bias ketika dijadikan acuan dalam ketepatan dalam pemberian opini oleh akuntan publik. Maka dari itu, laporan audit yang handal harus berdasarkan oleh auditor dengan pengetahuan akuntansi dan audit yang baik pula. Berdasarkan pemaparan hasil rujukan penelitian tersebut, maka hipotesis yang 
diajukan adalah:

$\mathrm{H}_{3}$ : Pengetahuan akuntansi dan auditing berpengaruh terhadap Pemilihan Ketepatan pemberian Opini Audit.

\section{Pengaruh Skeptisme auditor Terhadap Pemilihan Ketepatan pemberian Opini Audit}

Berdasarkan hasil penelitian yang dilakukan oleh (Pardede, 2015) menyatakan bahwa variabel skeptisme profesional berpengaruh secara signifikan dan positif terhadap ketepatan pemberian opini audit. Yang mengartikan bahwa Skeptisme profesional auditor adalah suatu sikap yang mencakup pikiran yang selalu mempertanyakan dan tidak mudah percaya atas bukti-bukti audit yang diterima dari kliennya.

Sukendra,. I, P ., Yuniarta., G, A, Atmadja., A, T. (2015) didalam hasil penelitiannya menyatakan bahwa skeptisme profesional memiliki pengaruh signifikan dan positif terhadap ketepatan pemberian opini oleh auditor. Hal tersebut mengartikan bahwa Auditor diwajibkan dapat mempertanggungjawabkan kualitas informasi opini yang dihasilkan berdasarkan hasil audit yang telah dilakukan dengan baik dan benar. Maka dari itu, agar dapat tercapai standar tersebut, maka pengauditan harus direncanakan dan dilakukan dalam situasi yang berhubungan dengan penugasan audit dengan sikap skeptisme professionalnya. Berdasarkan pemaparan hasil rujukan penelitian tersebut, maka hipotesis yang diajukan adalah:

$\mathrm{H}_{4}$ : Skeptisme auditor berpengaruh terhadap Ketepatan pemberian Opini Audit.

\section{METODE PENELITIAN}

Populasi dalam penelitian ini adalah Auditor yang berkerja di Kantor Akuntan Publik di provinsi banten yang direncanakan diawal setalah dilakukan konfirmasi terlebih dahulu adalah sebanyak 130 auditor yang akan dijadikan responden. Namun dikarenakan tahun 2020 telah terjadi Pandemi Covid-19, hal tersebut menyebabkan sehingga auditor yang bersedia untuk menjadi responden dalam penelitian ini adalah sebanyak 30 orang. Adapun teknik pengambilan sampel yang digunakan dalam penelitian ini adalah purposive accidental sampling dengan kriteria Auditor sudah memiliki pengalaman kerja minimal dua tahun dan menduduki posisi senior auditor. Penyebaran kuesioner dilakukan secara langsung pada Kantor Akuntan Publik di Provinsi Banten. Penyebaran kuesioner ini dilaksanakan dengan mendatangi responden, dan membagikan angket berisi daftar pernyataan yang telah disusun oleh peneliti. Jenis data penelitian ini adalah data primer yang merupakan persepsi Auditor mengenai faktor-faktor yang mempengaruhi ketepatan dalam Pemberian Opini Audit.

\section{Ketepatan Pemberian Opini Audit (Y)}

Variabel dependen dalam penelitian ini adalah pendapat yang diberikan oleh auditor tentang kewajaran penyajian laporan keuangan perusahaan tempat auditor melakukan audit. Variabel ini diukur antara lain melalui pemberian opini yang sesuai dengan kriteriakriteria yang ditetapkan dalam macam-macam opini yaitu Wajar Tanpa Pengecualian (Unqualified Opinion), Wajar Tanpa Pengecualian Dengan Bahasa Penjelas (Unqualified Opinion with Explanatory Paragraph), Wajar Dengan Pengecualian (Qualified Opinion), Tidak Wajar (Adverse), dan Tidak Menyatakan Pendapat (Disclaimer). Instrumen yang dipakai untuk mengukur suatu Pemilihan Profesi Akuntan terdiri dari 11 butir pertanyaan.

\section{Independensi auditor $\left(\mathbf{X}_{1}\right)$}

Indepedensi Auditor dalam penelitian ini adalah auditor harus secara intelektual jujur. Untuk diakui pihak lain sebagai orang yang independen, harus bebas dari setiap kewajiban terhadap kliennya dan tidak mempunyai suatu kepentingan dengan kliennya, apakah itu manajemen perusahaan atau pemilik perusahaan. Instrumen yang dipakai untuk mengukur suatu Pemilihan Profesi Akuntan terdiri dari 7 butir pertanyaan. Indikator tersebut adalah meliputi kebebasan akan mendapatkan informasi terkait laporan yang sedang diaudit dan kebebasan atas intervensi tekanan dari klien yang bertentangan dengan prinsip integritas dan objektifitas audit. 


\section{Keahlian Audit $\left(\mathbf{X}_{2}\right)$}

Dalam pengerjaan tugasnya, auditor yang dapat dipercaya kualitas informasi laporan auditnya harus memiliki beberapa keahlian yang diperlukan dalam tugasnya, keahlian ini meliputi keahlian terkait bidang audit sesuai Pedoman Atandar Audit yang meliputi: merencanakan program kerja pemeriksaan, menyusun program kerja pemeriksaan, melaksanakan program kerja pemeriksaan, menyusun kertas kerja pemeriksaan, menyusun berita pemeriksaan, dan laporan hasil pemeriksaan. Instrumen yang dipakai untuk mengukur suatu Keahlian Audit terdiri dari 10 butir pertanyaan.

\section{Pengetahuan akuntansi dan auditing $\left(\mathbf{X}_{3}\right)$}

Sarana pendalaman audit dari pendidikan dan pelatihan formal dan nonformal seperti pengetahuan audit yang didapatkan dari frekuensi pengalaman khusus auditor dalam melakukan perkerjaan dalam proses audit, kegiatan seminar, loka karya serta pengarahan dari auditor senior atau rekan sejawat. Auditor yang handal harus menjalani pendidikan dan pelatihan teknis yang cukup dalam praktik akuntansi dan teknik auditing sehingga mampu mengerjakan tugasnya dengan handal dan relevan. Instrumen yang dipakai untuk mengukur suatu Pengetahuan akuntansi dan auditing terdiri dari 7 butir pertanyaan.

\section{Skeptisme Auditor $\left(\mathbf{X}_{4}\right)$}

Suatu sikap yang memunculkan keingintahuan auditor dalam keabsahan buti audit yang diterimanya dengan selalu mempertanyakan dan melakukan evaluasi secara skeptis terhadap bukti audit tersebut. Hal tersebut muncul dari pemikiran auditor bukan karena ketidakpercayaan atas bukti yang sudah diterima oleh kliennya, hanya saja auditor ingin memastikan bukti yang diterimanya terbebas dari kesalahan data. Maka sikap skeptisme ini harus dimiliki oleh auditor dalam pengerjaan tugasnya dalam pengerjaan auditnya. Selain memastikan data yang diterima terbebas dari kesalahan, karena ada reputasi yang mesti dijaga. biasanya auditor yang memiliki sikap ini adalah auditor yang sudah berafiliasi dengan kantor akuntan publik yang memiliki reputasi atau yang sudah memiliki reputasi baik dari lembaga keuangan sehingga auditor mudah-mudahan dapat lebih mempraktekan tingkat tertinggi dari suatu skeptisme profesionalnya. Instrumen yang dipakai untuk mengukur suatu Pemilihan Profesi Akuntan terdiri dari 11 butir pertanyaan.

\section{METODE ANALISIS DATA Uji Validitas}

Uji validitas dilakukan kepada instrumen Independensi, keahlian audit, Pengetahuan akuntansi dan audit, Skeptisme auditor dan Ketepatan Pemberian Opini Audit.

Berdasarkan hasil uji validitas Independensi diketahui $r$ hitung terendah 0,412 dan $\mathrm{r}$ hitung tertinggi $0,786 \mathrm{r}$ tabel pada tingkat kesalahan $5 \%$ dengan jumlah responden sebanyak 30 Auditor. Maka dapat diketahui nilai $r$ tabel sebesar 0.361. hal tersebut menunjukkan $\mathrm{r}$ hitung terendah $>\mathrm{r}$ tabel, sehingga butir instrumen tersebut dinyatakan valid. butir instrumen pada $r$ hitung terendah selanjutnya dapat dinyatakan valid. Berdasarkan Hasil uji tersebut, diperoleh kesimpulan yaitu 11 Item pertanyaan terntang Independensi dinyatakan valid.

Berdasarkan hasil uji validitas keahlian audit diketahui $\mathrm{r}$ hitung terendah 0,364 dan $\mathrm{r}$ hitung tertinggi $0,493 \mathrm{r}$ tabel pada tingkat kesalahan $5 \%$ dengan jumlah responden sebanyak 30 Auditor. Maka dapat diketahui nilai $r$ tabel sebesar 0.361. hal tersebut menunjukkan $\mathrm{r}$ hitung terendah $>\mathrm{r}$ tabel, sehingga butir instrumen tersebut dinyatakan valid. butir instrumen pada $r$ hitung terendah selanjutnya dapat dinyatakan valid. Berdasarkan Hasil uji tersebut, diperoleh kesimpulan yaitu 7 Item pertanyaan tentang keahlian audit dinyatakan valid.

Berdasarkan hasil uji validitas Pengetahuan akuntansi dan audit diketahui $r$ hitung terendah 0.491 dan $\mathrm{r}$ hitung tertinggi $0.797 \mathrm{r}$ tabel pada tingkat kesalahan $5 \%$ dengan jumlah responden sebanyak 30 Auditor. Maka dapat diketahui nilai $\mathrm{r}$ tabel sebesar 0.361. hal tersebut menunjukkan $\mathrm{r}$ hitung terendah $>\mathrm{r}$ tabel, sehingga butir instrumen tersebut dinyatakan valid. butir instrumen pada $r$ hitung terendah selanjutnya dapat dinyatakan valid. Berdasarkan Hasil uji tersebut, diperoleh kesimpulan yaitu 10 Item pertanyaan tentang Pengetahuan akuntansi dan 
audit dinyatakan valid.

Berdasarkan hasil uji validitas Skeptisme auditor diketahui $r$ hitung terendah 0,422 dan $r$ hitung tertinggi $0,572 \mathrm{r}$ tabel pada tingkat kesalahan $5 \%$ dengan jumlah responden sebanyak 30 Auditor. Maka dapat diketahui nilai $r$ tabel sebesar 0.361. hal tersebut menunjukkan $\mathrm{r}$ hitung terendah $>\mathrm{r}$ tabel, sehingga butir instrumen tersebut dinyatakan valid. butir instrumen pada $r$ hitung terendah selanjutnya dapat dinyatakan valid. Berdasarkan Hasil uji tersebut, diperoleh kesimpulan yaitu 7 Item pertanyaan tentang Skeptisme auditor dinyatakan valid.

Berdasarkan hasil uji validitas Ketepatan Pemberian Opini Audit.diketahui $\mathrm{r}$ hitung terendah 0.555 dan $r$ hitung tertinggi $0.824 \mathrm{r}$ tabel pada tingkat kesalahan $5 \%$ dengan jumlah responden sebanyak 30 Auditor. Maka dapat diketahui nilai $r$ tabel sebesar 0.361. hal tersebut menunjukkan $\mathrm{r}$ hitung terendah $>\mathrm{r}$ tabel, sehingga butir instrumen tersebut dinyatakan valid. butir instrumen pada $r$ hitung terendah selanjutnya dapat dinyatakan valid. Berdasarkan Hasil uji tersebut, diperoleh kesimpulan yaitu 11 Item pertanyaan tentang Ketepatan Pemberian Opini Audit.

\section{Uji Reabilitas}

Dimana hasil dari perhitungan Alpha Cronbach's tersebut kemudian dikonsultasikan dengan ketentuan bahwa suatu variabel dikatakan variabel jika memberikan nilai Alpha Cronbach's > 0,60 (Ghozali, 2011).

Tabel 2

Hasil Uji Reabilitas

\begin{tabular}{l|c|c|c}
\hline \multicolumn{1}{c|}{ Variabel } & $\begin{array}{c}\text { Jumlah } \\
\text { Butir } \\
\text { Pertanyaan }\end{array}$ & $\begin{array}{c}\text { Cronbach's } \\
\text { Alpha }\end{array}$ & Keterangan \\
\hline $\begin{array}{l}\text { Ketepatan Pemberian } \\
\text { Opini Audit }\end{array}$ & 11 Butir & 0,704 & Reliabel \\
\hline Independensi & 7 Butir & 0,683 & Reliabel \\
\hline Keahlian Audit & 10 Butir & 0,749 & Reliabel \\
\hline $\begin{array}{l}\text { Pengetahuan Akuntansi } \\
\text { dan Audit }\end{array}$ & 7 Butir & 0.616 & Reliabel \\
\hline Skeptisme Auditor & 11 Butir & 0,743 & Reliabel \\
\hline Sumber: Data diolah & & &
\end{tabular}

Sumber: Data diolah

Tabel diatas menunjukkan nilai cronbach's alpha atas variabel Ketepatan Pemberian Opini Audit sebesar 0,704, Independensi sebesar 0,683, Keahlian Audit sebesar 0,749, Pengetahuan Akuntansi dan Audit sebesar 0,616 dan Skeptisme Auditor sebesar 0,743. Dengan demikian, dapat disimpulkan bahwa pernyataan dalam kuesioner ini reliabel karena mempunyai nilai cronbach's alpha lebih besar dari 0,60. Hal ini menunjukkan bahwa setiap item pernyataan yang digunakan akan mampu memperoleh data yang konsisten yang berarti bila pernyataan itu diajukan kembali akan diperoleh jawaban yang relatif sama dengan jawaban sebelumnya.

\section{Data Demografi Responden}

\section{Tabel 1}

Data Demografi Responden

\begin{tabular}{|c|c|c|c|c|}
\hline No. & \multicolumn{2}{|c|}{ Data Demografi } & Frequency & Percent \\
\hline \multirow[t]{2}{*}{1} & \multirow[b]{2}{*}{ Jenis Kelamin } & Laki-laki & 20 & 66.7 \\
\hline & & Perempuan & 10 & 33.3 \\
\hline \multirow[t]{5}{*}{2} & \multirow{5}{*}{ Umur } & $<25$ Tahun & 3 & 10.0 \\
\hline & & 26 - 30 Tahun & 10 & 33.3 \\
\hline & & $31-35$ Tahun & 8 & 26.7 \\
\hline & & 36 - 40 Tahun & 6 & 20.0 \\
\hline & & $>41$ Tahun & 3 & 10.0 \\
\hline \multirow[t]{4}{*}{3} & \multirow{4}{*}{ Lama Bekerja } & 1-2 Tahun & 3 & 10.0 \\
\hline & & 3-4 Tahun & 19 & 63.3 \\
\hline & & 5-6 Tahun & 6 & 20.0 \\
\hline & & $>6$ Tahun & 2 & 6.7 \\
\hline \multirow[t]{3}{*}{4} & \multirow{3}{*}{ Jabatan } & Manager & 0 & 0 \\
\hline & & Supervisor & 1 & 3.3 \\
\hline & & Senior & 29 & 96.7 \\
\hline \multirow[t]{3}{*}{5} & \multirow{3}{*}{ Pendidikan } & D3 & 3 & 10.0 \\
\hline & & $\mathrm{S} 1$ & 25 & 83.3 \\
\hline & & $\mathrm{S} 2$ & 2 & 6.7 \\
\hline \multirow[t]{4}{*}{6} & \multirow{4}{*}{ Pelatihan } & Brevet A & 4 & 13.3 \\
\hline & & Brevet B & 2 & 6.7 \\
\hline & & Brevet C & 13 & 43.3 \\
\hline & & Lainnya & 11 & 36.7 \\
\hline
\end{tabular}

Sumber: Data diolah

Berdasarkan tabel tersebut dapat terlihat rata-rata frequency dan persentase responden berdasarkan pengolahan data demografi responden.

\section{Uji Statistik Deskriptif}

Tabel 2

\section{Hasil Uji Statistik Deskriptif}

\begin{tabular}{l|c|c|c|c|c}
\hline & N & Min & Max & Mean & $\begin{array}{c}\text { Std. } \\
\text { Deviation }\end{array}$ \\
\hline Independensi & 30 & 41 & 54 & 48.40 & 3.616 \\
\hline Keahlian Audit & 30 & 24 & 30 & 26.60 & 1.276 \\
\hline $\begin{array}{l}\text { Pengetahuan } \\
\text { Akuntansi Dan } \\
\text { Auditing }\end{array}$ & 30 & 35.00 & 45.00 & 38.900 & 2.7711 \\
\hline Skeptisme Auditor & 30 & 21.00 & 28.00 & 25.667 & 1.8631 \\
\hline $\begin{array}{l}\text { Ketepatan Pemberian } \\
\text { Opini Audit }\end{array}$ & 30 & 39 & 49 & 44.93 & 2.420 \\
\hline Valid N (Listwise) & 30 & & & & \\
\hline \multicolumn{7}{|l|}{ Sumber: Data dih }
\end{tabular}

Sumber: Data diolah 
Tabel diatas menjelaskan bahwa pada variabel Independensi jawaban minimum responden sebesar 41 dan maksimum sebesar 54, dengan rata-rata total jawaban 48,40 dan standar deviasi sebesar 3,616. Variabel Keahlian Audit jawaban minimum responden sebesar 24 dan maksimum sebesar 30, dengan rata-rata total jawaban 26,60 dan standar deviasi sebesar 1,276. Variabel Pengetahuan Akuntansi dan Auditing jawaban minimum responden sebesar 35 dan maksimum sebesar 45, dengan rata-rata total jawaban 38,90 dan standar deviasi sebesar 2,7711. Variabel Skeptisme Auditor jawaban minimum responden sebesar 21 dan maksimum sebesar 28, dengan rata-rata total jawaban 25,66 dan standar deviasi sebesar 1,863. Pada variabel Ketepatan pemberian Opini Audit minimum jawaban responden sebesar 39 dan maksimum sebesar 49, dengan rata-rata total jawaban 44,93 dan standar deviasi sebesar 2,420.

\section{HASIL DAN PEMBAHASAN}

\section{Hasil Analisis Uji Normalitas}

Hasil output dari uji normalitas pada tabel diatas memperlihatkan bahwa nilai signifikansi Kolmogorov-Smirnov sebesar 0,698 , ini menunjukan bahwa nilai signifikansi diatas 0,05 sehingga dapat disimpulkan data pada kuesioner mempunyai distribusi normal.

\section{Tabel 3}

Uji Normalitas

One-Sample Kolmogorov-Smirnov Test

\begin{tabular}{ll|r}
\hline & & \multicolumn{2}{|c}{$\begin{array}{c}\text { Standardized Predicted } \\
\text { Value }\end{array}$} \\
\hline $\mathrm{N}$ & & 30 \\
Normal Parameters ${ }^{\mathrm{a}}$ & Mean & .0000000 \\
& Std. Deviation & 1.00000000 \\
Most Extreme Differences & Absolute & .129 \\
& Positive & .129 \\
& Negative & -.082 \\
Kolmogorov-Smirnov Z & & .708 \\
Asymp. Sig. (2-tailed) & .698 \\
\hline a. Test distribution is Normal. & \\
Sumber: Data diolah &
\end{tabular}

\section{Hasil Analisis Uji Multikolinieritas}

Tabel 4

Uji Multikolinieritas

\begin{tabular}{l|c|c}
\hline \multicolumn{1}{c|}{ Variabel } & Tolerance & VIF \\
\hline Independensi & .927 & 1.079 \\
\hline Keahlian Audit & .701 & 1.427 \\
\hline $\begin{array}{l}\text { Pengetahuan Akuntansi } \\
\text { dan Auditing }\end{array}$ & .669 & 1.494 \\
\hline
\end{tabular}

\begin{tabular}{l|l|l}
\hline Skeptisme Auditor & .889 & 1.125 \\
\hline Sumber
\end{tabular}

Sumber: Data diolah

Berdasarkan tabel diatas dapat dilihat bahwa nilai tolerance dari variabel Independensi sebesar 0,927 lebih besar dari 0,1 dengan nilai VIF sebesar 1,079 lebih kecil dari 10, untuk nilai tolerance dari variabel Keahlian Audit sebesar 0,701 lebih besar dari 0,1 dengan nilai VIF sebesar 1,427 lebih kecil dari 10. Lalu, Pengetahuan Akuntansi dan Auditing sebesar 0,669 lebih besar dari 0,1 dengan nilai VIF sebesar 1,494 lebih kecil dari 10. Dan Skeptisme Auditor sebesar 0,889 lebih besar dari 0,1 dengan nilai VIF sebesar 1,125 lebih kecil dari 10. Dari hasil tersebut dapat disimpulkan variabel Independensi, Keahlian Audit, Pengetahuan Akuntansi dan Audit dan Skeptisme Auditor tidak mengalami gejala multikolinearitas.

\section{Hasil Analisis Uji Heteroskedastisitas}

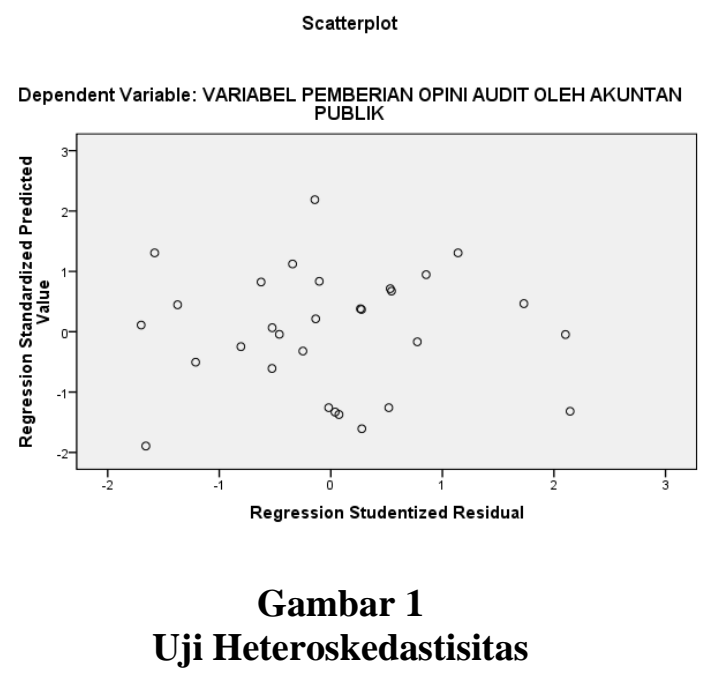

Hasil penelitian pada kuesioner dinyatakan terjadi heteroskedastisitas, apabila variasi variabel satu pengamatan dengan pengamatan yang lain berbeda. Berdasarkan hasil uji heteroskedastisitas pada gambar, maka dapat dilihat titik-titik menyebar secara acak pada grafik scatterplot. Dengan demikian dapat dinyatakan bahwa pada penelitian ini tidak terjadi heteroskedastisitas. 
Hasil Analisis Uji Autokorelasi

Tabel 5

Uji Normalitas

\begin{tabular}{l|r}
\hline Model & \multicolumn{2}{|c}{ Durbin-Watson } \\
\hline 1 & \multicolumn{2}{c}{2,754} \\
\hline \multicolumn{2}{l}{ Sumber: Data diolah }
\end{tabular}

Tabel 5 menunjukkan bahwa nilai Durbin-Watson adalah sebesar 2,754. Nilai batas atas (dL) pada tabel Durbin-Watson dengan signifikansi 5\% dan jumlah sampel 30 dengan $(\mathrm{k}=4)$ memiliki nilai 1.1426 . Nilai pada batas bawah (4-dU) memiliki nilai 2

.2614 Karena nilai DW 2,754 lebih

kecil dari batas atas (4-dU) 2.2614 dan lebih besar dari (dL) 1.1426, maka dapat disimpulkan bahwa tidak terdapat autokorelasi positf atau negatif.

\section{Hasil Analisis Regresi Linier Berganda}

Tabel 6

Uji Regresi Linier Berganda

Coefficients $^{a}$

\begin{tabular}{|c|c|c|c|c|}
\hline \multirow[b]{2}{*}{ Model } & \multicolumn{2}{|c|}{$\begin{array}{l}\text { Unstandardized } \\
\text { Coefficients }\end{array}$} & \multirow{2}{*}{$\begin{array}{c}\begin{array}{c}\text { Standardized } \\
\text { Coefficients }\end{array} \\
\text { Beta }\end{array}$} & \multirow[b]{2}{*}{$t$} \\
\hline & B & Std. Error & & \\
\hline 1 (Constant) & 12.115 & 10.799 & & 1.122 \\
\hline Independensi & .246 & .109 & .368 & 2.264 \\
\hline Keahlian Audit & -.118 & .355 & -.062 & -.332 \\
\hline Pengetahuan Akuntansi Dan Auditing & .383 & .167 & .439 & 2.296 \\
\hline Skeptisme Auditor & .355 & .216 & .273 & 1.648 \\
\hline
\end{tabular}

\section{Dimana :}

$\begin{array}{ll}\mathrm{a} & : \text { Konstanta } \\ \mathrm{b}_{1}, \mathrm{~b}_{2}, \mathrm{~b}_{3}, \mathrm{~b}_{4} & \text { : Koefesien regresi } \\ \mathrm{Y} & : \text { Ketepatan Pemberian Opini } \\ & \text { Audit } \\ \mathrm{X}_{1} & : \text { Independensi } \\ \mathrm{X}_{2} & : \text { Keahlian Audit } \\ \mathrm{X}_{3} & : \text { Pengetahuan Akuntansi dan } \\ & \text { Audit } \\ \mathrm{X}_{4} & : \text { Skeptisme Auditor } \\ \mathrm{e} & : \text { Error }\end{array}$

Tabel 7

Uji R Square

\begin{tabular}{|c|c|c|c|c|}
\hline Model & $\mathrm{R}$ & $\begin{array}{c}\mathrm{R} \\
\text { Square }\end{array}$ & $\begin{array}{l}\text { Adjusted } \\
\text { R Square }\end{array}$ & Std. Error of the Estimate \\
\hline 1 & $.623^{\mathrm{a}}$ & .388 & .290 & 2.039 \\
\hline
\end{tabular}

Tabel diatas menunjukkan nilai $\mathrm{R}$ sebesar 0,623 atau $62,3 \%$. Hal ini berarti bahwa hubungan atau korelasi antara Ketepatan Pemberian Opini Audit dengan Independensi, Keahlian Audit, Pengetahuan Akuntansi dan Auditing dan Skeptisme Auditor adalah tinggi karena berada kisaran 0,60-0,699. Nilai R Square sebesar 0,388 atau $38,8 \%$, ini menunjukkan bahwa variabel Ketepatan Pemberian Opini Audit yang dapat dijelaskan oleh variabel Independensi, Keahlian Audit, Pengetahuan Akuntansi dan Auditing dan Skeptisme Auditor adalah sebesar $38,8 \%$, sedangkan sisanya sebesar 0,612 atau $61,2 \%$ dijelaskan oleh faktor-faktor lain yang tidak disertakan dalam model penelitian ini.

\section{Pengaruh Independensi terhadap Ketepatan Pemberian Opini Audit.}

Nilai $t_{\text {hitung }}$ Independensi sebesar 2.264, sementara tabel dengan tingkat $\alpha=5 \%$, df (n$\mathrm{k})=30-4$ didapat nilai $\mathrm{t}_{\text {tabel }}$ sebesar 1.7056 . Dengan demikian $t_{\text {hitung }}$ Independensi $2.264>$ $\mathrm{t}_{\text {tabel }} 1.7056$ dan nilai sig. $0,032<0,05$ maka dapat disimpulkan bahwa variabel Independensi dalam penelitian ini memiliki pengaruh terhadap Ketepatan Pemberian ${ }_{032}^{27}$ Opini Audit. Independensi mempunyai ${ }_{74}$ koefisien regresi kearah Positif sebesar 0,246 ${ }_{038} 24,6 \%$ ). Hal ini berarti jika semakin tinggi Independensi yang dimiliki oleh auditor maka hal tersebut akan membuat auditor menjadi tidak akan terpengaruh oleh bujukan atau arahan yang menyebabkan tidak relevannya hasil laporan audit yang dibuatnya. Hasil tersebut sesuai dengan hasil signifikannya variabel Independensi terhadap Ketepatan dalam pemberian Opini Audit. Independensi disini menunjukkan bahwa sikap mental auditor yang bekerja di Kantor Akuntan Publik Provinsi Banten akan menilai secara obyektif dan mempergunakan pertimbangan tidak memihak selama melakukan pemeriksaan atau audit dan selalu menempatkan diri untuk tidak memihak kepada siapapun dalam melakukan tugas auditnya. Maka dapat dikatakan jika semakin independensinya seorang auditor, maka akan semakin terbebas auditor bekerja di Kantor Akuntan Publik Provinsi Banten dari pengaruh pihak lain sehingga pertimbangan pemberian opini oleh auditor akan bebas dari campur tangan pihak lain terutama klien. 


\section{Pengaruh Keahlian Audit terhadap Ketepatan Pemberian Opini Audit.}

Nilai $t_{\text {hitung }}$ Keahlian Audit sebesar 0.062 , sementara $t_{\text {tabel }}$ dengan tingkat $\alpha=5 \%$, df $(n-k)=30-4$ didapat nilai $t_{\text {tabel }}$ sebesar 1.7056. Dengan demikian $t_{\text {hitung }}$ Keahlian Audit $-0.062>t_{\text {tabel }} 1.7056$ dan nilai sig. $0,742>0,05$ maka dapat disimpulkan bahwa variable Keahlian Audit dalam penelitian ini tidak memiliki pengaruh terhadap Ketepatan Pemberian Opini Audit. Keahlian Audit mempunyai koefisien regresi kearah negative sebesar $-0.118(-11,8 \%)$. Hal ini berarti jika semakin jarangnya seorang auditor untuk mengikuti kegiatan seminar, lokakarya atau bahkan jarang berkomunikasi dengan rekan auditor sejawat yang sudah lebih senior terkait isu terkini terkait dengan teknik audit disaat penugasan audit di perusahaan. Maka akan mempengaruhi Keahlian Audit disaat penugasan dilapangan. Hasil tersebut sesuai dengan tidak signifikannya variabel keahlian terhadap Ketepatan dalam pemberian Opini Audit. Hal ini terjadi dikarenakan jumlah responden sebesar 43\% mayoritas auditor yang bekerja di Kantor Akuntan Publik di Provinsi Banten hanya memiliki keahlian dalam perpajakan tingkat Brevet $\mathrm{C}$ ketimbang mengikuti Pelatihan atau ujian sertifikasi yang diadakan oleh IAI dan IAPI. Namun, pada dasarnya suatu keahlian audit memiliki kausalitas yang tidak signifikan terhadap ketepatan pemberian opini akuntan publik yang berdasarkan informasi dari laporan audit, sehingga tidak menutup kemungkinan auditor yang sudah memiliki kecakapan dalam keahlian audit dapat menemukan metode temuan audit yang sesuai dengan bidang jenis usahanya dan belum tentu metode yang dimilikinya tersebut bisa diungkapkan dan dipahami dengan mudah oleh para akuntan publik atau rekan sejawatnya.

\section{Pengaruh Pengetahuan Akuntansi dan Auditing terhadap Ketepatan Pemberian Opini Audit.}

Nilai thitung Pengetahuan Akuntansi dan Auditing sebesar 2.296, sementara $t_{\text {tabel }}$ dengan tingkat $\alpha=5 \%$, df $(\mathrm{n}-\mathrm{k})=30-4$ didapat nilai $t_{\text {tabel }}$ sebesar 1.7056. Dengan demikian $t_{\text {hitung }}$ Pengetahuan Akuntansi dan Auditing $2.296>$ $\mathrm{t}_{\text {tabel }} 1.7056$ dan nilai sig. $0,030<0,05$ maka dapat disimpulkan bahwa variabel Pengetahuan Akuntansi dan Auditing dalam penelitian ini memiliki pengaruh terhadap
Ketepatan Pemberian Opini Audit. Pengetahuan Akuntansi dan Auditing mempunyai koefisien regresi kearah positif sebesar $0.383(38,3 \%)$. Hasil tersebut sesuai dengan signifikannya variabel Pengetahuan Akuntansi dan Auditing terhadap Ketepatan dalam pemberian Opini Audit. Hal tersebut mengartikan bahwa segala tindakan dan keputusan yang diambil auditor yang bekerja di Kantor Akuntan Publik di Provinsi Banten dalam melakukan pengerjaan auditnya berdasarkan kecakapan tentang pengetahuan akuntansi dan auditing yang dimilikinya. Hal tersebut disadari bahwa dalam melakukan pengauditan yang dilakukannya akan selalu terkait dengan bidang ilmu akuntansi dan auditing. Sehingga penguasaaan pengetahuan yang baik tentang akuntansi dan auditing merupakan syarat yang tidak bisa ditawar, karena auditor pasti akan mengalami kendala disaat menjalankan pekerjaan auditnya tersebut, sehingga akan membuat laporan audit menjadi tidak memiliki nilai informasi yang sesuai dengan batas waktu audit yang telah disekepakati. Hal ini berarti mengartikan bahwa jika semakin semakin tinggi Pengetahuan Akuntansi dan Auditing yang diniliki oleh seorang Auditor, maka hal tersebut akan mempengaruhi informasi kualitas laporan auditnya.

\section{Pengaruh Skeptisme Auditor terhadap Ketepatan Pemberian Opini Audit.}

Nilai thitung Skeptisme Auditor sebesar 1.648 , sementara $t_{\text {tabel }}$ dengan tingkat $\alpha=5 \%$, df $(\mathrm{n}-\mathrm{k})=30-4$ didapat nilai $\mathrm{t}_{\text {tabel }}$ sebesar 1.7056. Dengan demikian $t_{\text {hitung }}$ Skeptisme Auditor $1.648<\mathrm{t}_{\text {tabel }} 1.7056$ dan nilai sig. $0,112>0,05$ maka dapat disimpulkan bahwa variabel Skeptisme Auditor dalam penelitian ini tidak memiliki pengaruh terhadap Ketepatan Pemberian Opini Audit. Skeptisme Auditor mempunyai koefisien regresi kearah Positif sebesar 0,355 (35,5\%). Hasil tersebut sesuai dengan tidak signifikannya variabel Skeptisme Auditor terhadap Ketepatan dalam pemberian Opini Audit. Hasil tersebut sesuai dengan tidak signifikannya variabel Skeptisme Auditor terhadap Ketepatan dalam pemberian Opini Audit.

Suatu skeptisme profesional wajib digunakan oleh seorang auditor supaya dapat menemukan dan menghimpun bukti sebanyakbanyaknya, dengan batas kriteria standar pemeriksaan, sehingga mencukupi bagi auditor untuk melaksanakan tugas auditnya dalam 
pemeriksaan laporan keuangan kliennya. Tetapi terkadang dilapangan auditor menerapkan sikap skeptisme profesional yang tinggi tanpa menggunakan batas kriteria standar pemeriksaan yang mecakup keahliannya dan mempertimbangkan batasan waktu audit, sehingga hal tersebut mengakibatkan auditor akan lebih banyak terfokus dalam mengevaluasi bukti audit yang diterima tanpa melihat batas waktu. Jika terlalu banyak waktu yang dihabiskan umtuk mengevaluasi bukti audit, maka mengakibatkan waktu untuk menyelesaikan proses audit selanjutnya akan semakin singkat, sehingga hasil audit akan kurang akurat dan pemberian opini oleh auditor akan kurang tepat.

\section{KESIMPULAN}

Hasil Penelitian dari pengujian ini menghasilkan bahwa Variabel independensi dan Pengetahuan Akuntansi dan Audit secara parsial berpengaruh terhadap Ketepatan Pemberian Opini Audit. Sedangkan variabel Keahlian Audit dan Skeptisme Auditor secara parsial tidak memiliki pengaruh terhadap Ketepatan Pemberian Opini Audit.

\section{DAFTAR PUSTAKA}

Abbas, Dirvi Surya, Basuki Basuki, And Muhammad Rifai. "Pengaruh Persepsi Penghargaan Finansial Dan Nilai-Nilai Sosial Terhadap Pemilihan Profesi Akuntan (Mahasiswa Prodi Akuntansi Umt)." Simposium Nasional Mulitidisiplin (Sinamu) (2019).

Abbas, Dirvi Surya, And Basuki Basuki. "Pengaruh Profesionalime Auditor Dan Pengalaman Auditor Terhadap Audit Judgement (Kap Provinsi Banten)." Simposium Nasional Mulitidisiplin (Sinamu) (2019).

Merici, C. A., Halim, A., \& Wulandari, R. (2016). Pengaruh Skeptisisme Profesional, Pengalaman Audit, Keahlian Audit, Independensi, Dan Kompetensi Terhadap Ketepatan Pemberian Opini Auditor. Jurnal Riset Mahasiswa Akuntansi, 4 (1). Retrieved from http://ejournal.unikama.ac.id/inde x.php/jrma/article/view/1202

Pelu, M. F. AR., Abduh, M., \& Hesty H. (2018). pengaruh skeptisme profesional auditor, situasi audit, etika profesi, pengalaman dan keahlian auditor terhadap ketepatan pemberian opini audit oleh akuntan public. Jurnal Ilmiah Akuntansi Peradaban, 4 (2). Retrieved from http://journal.uinalauddin.ac.id/index.php/jiap/article/ view/6928

Marheni, L \&., Cahyono, Y. T. (2018). Pengaruh Skeptisme Profesional, Pengalaman Auditor, Keahlian Audit, dan Independensi Terhadap Ketepatan Pemberian Opini oleh Auditor. Thesis, Universitas Muhammadiyah Surakarta. Retrieved from http://eprints.ums.ac.id/65996/

Prasetya, I.W.A., \& Sari, M. M. R. (2014). independensi, profesionalisme, dan skeptisme profesional auditor sebagai prediktorketepatan pemberian opini auditor. E-Jurnal Akuntansi Universitas Udayana. 9 (2) : 273-284. ISSN: 2302-8556 Retrieved from https://ojs.unud.ac.id/index.php/Aku ntansi/article/view/8594/7777

Pardede, H,. Rasuli, M,. Silfi, A. (2015). pengaruh profesional judgement, pengalaman, keahlian, pengetahuan akuntansi dan audit serta skeptisme auditor terhadap ketepatan pemberian opini auditor. Jurnal Online Mahasiswa Fakultas Ekonomi. 2 (1). Retrieved from https://jom.unri.ac.id/index.php/J OMFEKON/article/view/8164

Kautsarrahmelia., T, (2013), Pengaruh Independensi, Pengetahuan Akuntansi Dan Auditing Serta Skeptisme Profesional Auditor Terhadap Ketepatan Pemberian Opini Audit Oleh Akuntan Publik, Skripsi, Universitas Islam Negeri Syarif Hidayatullah. Retrieved from 
http://repository.uinjkt.ac.id/dspac e/bitstream/123456789/23987/1/T

ANIA\%20KAUTSARRAHMELI

A.pdf

Sukendra,. I, P ., Yuniarta., G, A, Atmadja., A, T. (2015). Pengaruh Skeptisme Profesional, Pengalaman Auditor,dan Keahlian Audit Terhadap Ketepatan Pemberian Opini oleh Auditor. E-Journal S1 Ak Universitas Pendidikan Ganesha. Vol.3 (1). Retrieved from https://ejournal.undiksha.ac.id/index. $\mathrm{php} / \mathrm{S} 1 \mathrm{ak} / \mathrm{article} / \mathrm{view} / 4690$

CNN Indonesia. (2020). Kronologi Kasus Jiwasraya, Gagal Bayar Hingga Dugaan Korupsi. Rabu, 08/01/2020 14:50 WIB. Retrieved from

https://www.cnnindonesia.com/ekon omi/20200108111414-78-

463406/kronologi-kasus-jiwasrayagagal-bayar-hingga-dugaan-korupsi

Jurnal.Akuntansi.Keuangan.

(2011).

Deloitte Dituntut Tujuh Setengah Milyar Dollar. www.jurnalakuntansikeuangan.co m. Jakarta

Wardoyo., T, S, \& Seruni, P, A. (2011). pengaruh pengalaman dan pertimbangan profesional auditor terhadap kualitas bahan bukti audit yang dikumpulkan (studi kasus pada kantor akuntan publik di bandung). Akurat Jurnal Ilmiah Akuntansi. No. 06. Tahun ke-2. September-Desember. Retrieved from

https://www.neliti.com/id/publicat ions/220280/pengaruhpengalaman-dan-pertimbanganprofesional-auditor-terhadapkualitas-bahan 